\title{
Responses of the monkey oviduct to transmural electrical stimulation and to drugs
}

\author{
J. H. Widdicombe*, A. Johns and D. M. Paton \\ Department of Pharmacology, University of Alberta, Edmonton, Alberta T6G 2H7, Canada
}

In monkeys, as in man, the time required for ovum transport through the oviduct is about 3 days (Eddy, Garcia, Kraemer \& Pauerstein, 1976). This period appears essential for normal fertility because eggs passing too quickly or too slowly through the oviduct fail to implant (Bennett, 1974). Although transport through the ampulla may be mediated by cilia (Blandau \& Verdugo, 1976), the isthmus is comparatively muscular and well innervated and may delay ovum transport by a sphincterlike action. Prostaglandins and catecholamines are known to alter the muscular activity of human and rabbit oviducts and it is possible that changes in the levels of these drugs, or in the sensitivity of the tissues to them, may control egg transport (Hodgson \& Eddy, 1975; Spilman \& Harper, 1975). In the present study the contractile responses of the monkey oviduct to various drugs and to transmural electrical stimulation have been examined in the hope of increasing understanding of the regulation of ovum transport in this species.

Tissues were obtained from mature female crabeating macaques (Macaca fascicularis). Uteri with their attached oviducts were removed under halothane anaesthesia and were placed in cold Krebs solution. Each oviduct was then separated from the uterus and the attached connective tissue and ligaments dissected away. One 4-mm and two 2-mm lengths of tube were then obtained from both the isthmic and the ampullary regions. The shorter lengths were connected together with thread in the form of rings for recording of circular muscle activity; the longer sections were suspended longitudinally. Both types of preparation were suspended in $\mathrm{Krebs}$ solution at $37^{\circ} \mathrm{C}$ under a tension of 490 or 980 dyn. The Krebs solution consisted of $(\mathrm{mM}): \mathrm{Na}^{+}, 139 ; \mathrm{K}^{+}, 5 \cdot 4 ; \mathrm{Ca}^{2+}, 2 \cdot 5 ; \mathrm{Mg}^{2+}, 1 \cdot 2 ; \mathrm{Cl}^{-}$, $129 ; \mathrm{HCO}_{3}^{-}, 22 ; \mathrm{H}_{2} \mathrm{PO}_{4}^{-}, 1 \cdot 2 ;$ D-glucose, $11 \cdot 1$, and was bubbled with $95 \% \mathrm{O}_{2}+5 \% \mathrm{CO}_{2}$. During transmural electrical stimulation, tissues were continuously superfused with Krebs solution at 1-2 $\mathrm{ml} / \mathrm{min}$. The medium had a $\mathrm{pH}$ of $7 \cdot 40 \pm 0.02$. Tension was recorded by using Grass FT03C transducers and displayed on Dynograph or Grass pen recorders.

Compounds were added to the organ baths, 5 or $10 \mathrm{ml}$ volume, as small (10-50 $\mu \mathrm{l})$ amounts of stock solutions. The baths were washed out with fresh Krebs solution when the tissues had produced a maximal response. Transmural electrical stimulation was generally for $60 \mathrm{sec}$ and consisted of biphasic pulses, of $1 \mathrm{msec}$ duration and supramaximal voltage, delivered at 2 to $29 \mathrm{~Hz}$. Tissues were allowed to equilibrate in $\mathrm{Krebs}$ solution at $37^{\circ} \mathrm{C}$ for $30 \mathrm{~min}$ before electrical stimulation or addition of drugs.

The hormonal status of each animal was determined by histological examination of the uterus and oviduct.

All the preparations were spontaneously active. Several types of activity were seen. Some preparations showed rapid repetitive spike-like contractions at frequencies of up to $10 / \mathrm{min}$. In others, large regular sustained contractions were seen at intervals of from 1 to several minutes. Frequently, both forms of rhythm were seen in the same preparation. In a few tissues the activity was irregular, while in others activity consisted of bursts of high-frequency contractions occurring at intervals of 5-10 min, the tissue being quiescent in the intervening periods. No particular form of spontaneous activity was characteristic of any hormonal state or portion of the oviduct.

The responses to transmural electrical stimulation of oviductal preparations from 12 monkeys were tested. It can be seen from the results in Table 1 that a response was produced in about $50 \%$ of the trials. The responsive tissues showed a threshold for response at about $8 \mathrm{~Hz}$. In the circular and U.S.A.

* Present address: Cardiovascular Research Institute, University of California, San Francisco, California 94143, 
Table 1. The responses of different parts of the oviduct of monkeys to transmural electrical stimulation at $20 \mathrm{~Hz}$

\begin{tabular}{lccccc}
\hline & \multicolumn{2}{c}{ Ampulia } & & \multicolumn{2}{c}{ Isthmus } \\
\cline { 2 - 3 } \cline { 5 - 6 } & Longitudinal & Circular & Longitudinal & Circular \\
\hline No response & 5 & 8 & & 6 & 7 \\
Contraction & 7 & 4 & & 3 & 5 \\
Relaxation & 0 & 0 & & 3 & 0 \\
\hline
\end{tabular}

longitudinal muscle of the ampulla and in the circular muscle of the isthmus the response was invariably a contraction. The longitudinal isthmus, however, contracted or relaxed with equal frequency. In no case was the response very great and was often obscured by the spontaneous activity of the tissue. Preparations from monkeys in the luteal phase were more sensitive than those from animals in the follicular phase of the cycle. In two of the three preparations in which the longitudinal isthmus relaxed in response to transmural stimulation, propranolol $\left(3.9 \times 10^{-6} \mathrm{M}\right)$ converted the relaxation to a contraction. When phentolamine $\left(10^{-5} \mathrm{M}\right)$ was tested it abolished the contractile responses of all types of oviductal musculature.

The effects of various compounds on the contractility of oviducts (number tested shown in parentheses) were examined: (-)-noradrenaline (11), prostaglandin F-2 $\alpha(11)$, acetylcholine (6), 5-hydroxytryptamine (3), prostaglandin E-2 (6), and histamine (12). All sections of the oviduct at all stages in the menstrual cycle were remarkably insensitive to all drugs, except histamine. Histamine, at concentrations greater than about $10^{-6} \mathrm{M}$, always induced a prolonged contraction but the muscle rapidly developed tachyphylaxis. (-)-Noradrenaline at concentrations of up to $3 \times 10^{-4} \mathrm{M}$ resulted in contraction or increased spontaneous activity, but even with the highest doses used it was sometimes ineffective. Acetylcholine $\left(3.4 \times 10^{-4} \mathrm{M}\right)$ had no action except for one instance of a contraction in a progesterone-dominant oviduct which was also unusually sensitive to other drugs. Prostaglandin F-2 $\alpha\left(1.4 \times 10^{-5} \mathrm{M}\right)$ generally caused contractions but was not always able to elicit a response. PGE-2, in doses of up to $2.8 \times 10^{-5} \mathrm{M}$, was generally without effect, although there was sometimes a diminution in the rate and amplitude of the spontaneous contractions. 5-Hydroxytryptamine (3-6 $\times 10^{-5} \mathrm{M}$ ) had virtually no effect, eliciting small contractions from some tissues. The responses of preparations from one oviduct to transmural electrical stimulation and various compounds are illustrated in Text-fig. 1. The similarity in the responses to transmural electrical stimulation and to exogenous noradrenaline was seen in all other tissues that responded to these treatments. Because of the response of the oviduct tissue to histamine, the effects of mepyramine on spontaneous activity were tested: a dose of $8.8 \times 10^{-5} \mathrm{M}$ abolished the response to a test dose of histamine, but was without effect on the spontaneous activity or tone.

The main finding of this study is the relative insensitivity of the monkey oviduct to transmural electrical stimulation and to drugs. In this respect, it differs markedly from the responses of rabbit and human oviducts. The rabbit oviduct always responded in vitro with a sustained contraction to transmural electrical stimulation and to noradrenaline (Johns \& Paton, 1975a, b). By contrast, the responses of the human oviduct in vitro appear to be markedly dependent on hormonal status; in the luteal phase, transmural electrical stimulation and noradrenaline are inhibitory, whereas responses are more variable in the follicular phase (Molnar, Johns, Paton, Daniel \& Beck, 1976; Moawad, Hedqvist \& Kim, 1976). Similarly, the effects of prostaglandins on the monkey oviduct appear to be much less marked than those reported in studies on rabbit and human oviducts (Spilman \& Harper, 1975). The monkey oviduct may not, therefore, be a good model for the human oviduct as its pharmacological characteristics differ significantly.

The relative insensitivity of the monkey oviduct to transmural electrical stimulation and to noradrenaline and prostaglandins suggest that the adrenergic innervation and generation of prostaglandins in the oviduct do not play a major role in the regulation of ovum transport in this species. The present study of responses in vitro may not accurately reflect responses in vivo. Ultrastructural 


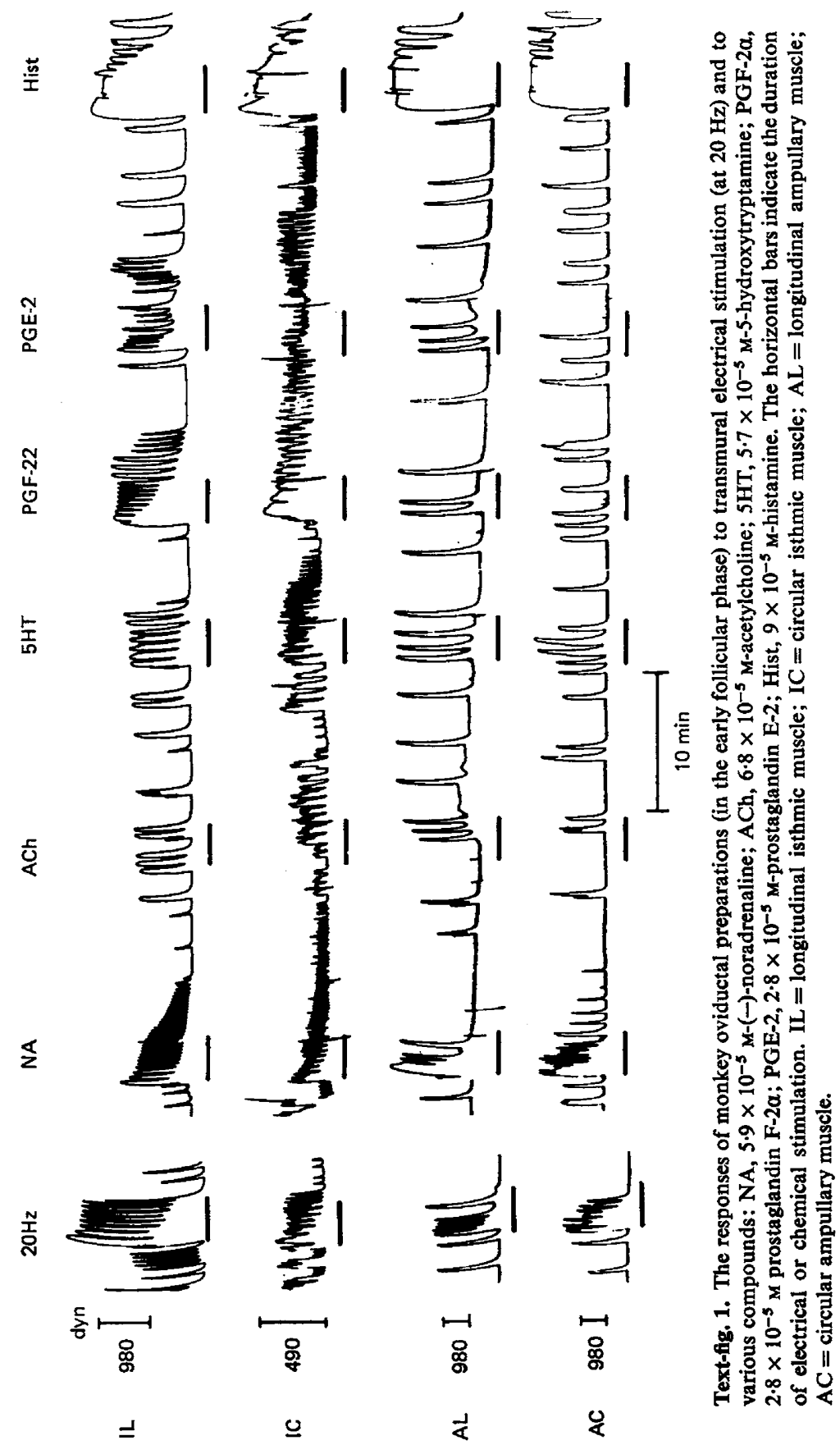


studies of the monkey oviduct have shown that only a small percentage of smooth muscle cells in the monkey oviduct are innervated by adrenergic nerves (J. H. Widdicombe, unpublished results), in keeping with the poor response to transmural electrical stimulation. Sympathectomy has minimal effects on ovum transport in the rabbit (Pauerstein, Hodgson, Fremming \& Martin, 1974) and on the fertility of female mice (Johns, Chlumecky, Cottle \& Paton, 1975), providing more direct evidence against a major role for adrenergic innervation of the oviduct in these species.

Supported by a grant from the World Health Organization. The prostaglandins used in the study were generously donated by Dr J. Pike, Upjohn Company.

\section{References}

Bennett, J.P. (1974) In Chemical Contraception, Ch. 6, pp. 99-132, Columbia University Press, New York.

Blandau, R.J. \& Verdugo, P. (1976) An overview of gamete transport-comparative aspects. In Ovum Transport and Fertility Regulation, pp. 138-146. Eds M. J. K. Harper, C. J. Pauerstein, C. E. Adams, E. M. Coutinho, H. B. Croxatto \& D. M. Paton. Scriptor, Copenhagen.

Eddy, C.A., Garcia, R.G., Kraemer, D.C. \& PauerSTEIN, C.J. (1976) Ovum transport in non-human primates. In Ovum Transport and Fertility Regulation, pp. 390-403. Eds M. J. K. Harper, C. J. Pauerstein, C. E. Adams, E. M. Coutinho, H. B. Croxatto \& D. M. Paton. Scriptor, Copenhagen.

Hodgson, B.J. \& EDDY, C.A. (1975) The autonomic nervous system and its relation to tubal ovum transport-a reappraisal. Gynecol. Invest. 6, 162185.

Johns, A., Chlumecky, J., Cottle, M.K.W. \& Paton, D.M. (1975) Effect of chemical sympathectomy and adrenergic agonists on the fertility of mice. Contraception 11, 563-570.

Johns, A. \& Paton, D.M. (1975a) Pharmacological characteristics of the response of rabbit oviduct to transmural stimulation. Archs. int. Pharmacodyn. Thér. 217, 22-28.
Johns, A. \& PAton, D.M. (1975b) Effect of cocaine and other drugs on sensitivity of the oestrogen-dominated isthmus of rabbit oviduct to noradrenaline. Can. J Physiol. Pharmacol. 53, 1172-1177.

Moawad, A.H., Hedqvist, P. \& Kim, M.H. (1976) Correlation of plasma estrogens and progesterone levels with the in vitro adrenergic responses in the isthmus of the human oviduct. In Ovum Transport and Fertility Regulation, pp. 276-292. Eds M. J. K. Harper, C. J. Pauerstein, C. E. Adams, E. M. Coutinho, H. B. Croxatto and D. M. Paton. Scriptor, Copenhagen.

Molnar, S., Johns, A., Paton, D.M., Daniel, E.E. \& BECK, R.P. (1976) Characteristics of responses of isolated human fallopian tube to transmural stimulation and to sympathomimetic amines. Archs int. Pharmacodyn. Thér. 220, 205-212.

Pauerstein, C.J., Hodgson, B., Fremming, B. \& MARTIN, J. (1974) Effects of sympathetic denervation of the rabbit oviduct on normal ovum transport and on transport modified by estrogen and progesterone. Gynecol. Invest. 5, 331-337.

SPILMAN, C.H. \& HarPeR, M.J.K. (1975) Effects of prostaglandins on oviductal motility and egg transport. Gynecol. Invest. 6, 186-205.

Received 1 November 1976 